\title{
Pertambahan Berat Badan Mencit (Mus musculus L.) Setelah Perlakuan Ekstrak Air Biji Pepaya (Carica papaya Linn.) Secara Oral Selama 21 Hari
}

\author{
Weight Gain Mice ( Mus musculus L. ) after Treatment Water Seed \\ Extract Papaya ( Carica papaya Linn . ) by Oral For 21 Days
}

\author{
Siti Muflichatun Mardiati*, Agung Janika Sitasiwi \\ Departemen Biologi, Fakultas Sains dan Matematika, Universitas Diponegoro \\ Jl. Prof. Soedarto, SH, Tembalang, Telp/Fax (024) 76480923 \\ Email:sm.mardiati@yahoo.com
}

Diterima 1 Juli 2016 / Disetujui 20 Agustus 2016

\begin{abstract}
ABSTRAK
Penelitian ini bertujuan untuk mengevaluasi efek ekstrak air biji pepaya terhadap reproduksi mencit betina ditinjau dari aspek pertambahan berat badan. Mencit strain Swiss Webster betina digunakan sebagai hewan uji. Hewan uji dibagi dalam 5 kelompok perlakuan, yaitu $\mathrm{K}(-)$, bahan perlakuan berupa akuades; $\mathrm{K}(+)$, bahan perlakuan sediaan pil kontrasepsi merk X dengan dosis ; P1, bahan perlakuan ekstrak air biji pepaya dengan dosis 1,4 mg/ekor/hari; P2, bahan perlakuan ekstrak air biji pepaya dengan dosis 3,5 mg/ekor/hari; P3, bahan perlakuan ekstrak air biji pepaya dengan dosis $1,4 \mathrm{mg} / \mathrm{ekor} / \mathrm{hari}$. Masing-masing kelompok perlakuan diulang 7 kali. Biji pepaya diperoleh dari pohon pepaya lokal diJawa Tengah. Pemberian bahan perlakuan secara oral selama 21 hari berturut-turut.Pemberian pakan dan minum dilakukan secara ad libitum. Parameter yang diamati adalah pertambahan berat badan, konsumsi pakan, dan konsumsi minum. Data yang diperoleh dianalisis dengan menggunakan analisis variansi dengan taraf kepercayaan 95\% dan uji lanjut Duncan.Hasil penelitian menunjukkan tidak terdapat perbedaan nyata terhadap pertambahan berat badan $(\mathrm{P}>0,05)$ padasemua kelompok hewan, terdapat perbedaan nyata pada konsumsi pakan $(\mathrm{P}<0,05)$ antara $\mathrm{K}(+)$ dan $\mathrm{P} 1$ dan terdapat perbedaan nyata pada konsumsi minum $(\mathrm{P}<0,05)$ antara $\mathrm{P} 2$ dengan $\mathrm{K}(+)$ dan $\mathrm{P} 1$. Kesimpulan penelitian adalah pemberian biji pepaya dengan paparan kronis tidak mempengaruhi pertambahan berat badan mencit.
\end{abstract}

Kata kunci: Mencit, biji pepaya, pertumbuhan, berat badan

\begin{abstract}
The aim of this experiment was to evaluate the effect of Carica papaya Linn aquoeus seeds extract on mice growth. Swiss Webster female mice (Mus musculus L.) were used as animal model. The animal model were divided into five treatment groups. The $\mathrm{K}$ - group was treated by aquadest, $\mathrm{K}+$ group was treated by hormonal contraceptives pills, C. papaya extract dosage1.4 (P1), 3.5 (P2) and 7 (P3) mg/animal/day. Each treatment group were repeated 7 times. Treatment was given during 21 days orally. The parametres that were obtained are body weight, feed comsumption and drink comsumption. This experiment showed that there was not significant difference on growth body weight $(\mathrm{P}>0,05)$ in all animal model groups but there were significant difference beetwen $\mathrm{P} 2$ and $\mathrm{K}(+)$ on feed comsumption $(\mathrm{P}<0,05)$; beetwen $\mathrm{P} 2$ and $\mathrm{P} 1, \mathrm{P} 2$ and $\mathrm{K}(+)$ on drink consumption $(\mathrm{P}<0,05)$. It concluded that the aquoeus extract of Carica papaya $\mathrm{L}$. seeds in cronic dosage not influenced on mice growth.
\end{abstract}

Keywords: Mice,C. Papaya seed, growth, body weight

\section{PENDAHULUAN}

Salah satu metode pengaturan fertilitas

dalam Program Keluarga Berencana adalah pemakaian sediaan hormon. Hasil riset beberapa peneliti menunjukkan bahwa metode pengaturan fertilitas secara hormonal menimbulkan efek samping yang cukup merugikan kesehatan penggunanya. Penggunaan sediaan hormon reproduksi menyebabkan efek samping 
obesitas/kegemukan (Lee, et al, 2009 ; Setyaningsih dkk., 2010; Ratnawati dkk., 2011). Hasil yang berbeda ditunjukkan oleh penelitian Hasan dkk. (2013) yang menyimpulkan bahwa Tidak terdapat hubungan antara penggunaan kontrasepsi hormonal dengan obesitas. Hal ini mungkin karena dipengaruhi oleh tingkat pendidikan yang cukup tinggi dan pekerjaan dalam hal ini sebagai ibu rumah tangga yang beraktivitas fisik cukup tinggi.

Kontrasepsi steroid yang mengandung progestin di dalam tubuh dapatberpengaruh terhadap metabolisme nutrisi, sedangkan estrogen menyebabkandeposisi dari sejumlah besar lemak pada jaringan subkutan dan dapatmenyebabkan terjadinya retensi natrium dan air oleh tubulus ginjal, efek tersebutnormalnya ringan dan jarang bermakna (Guyton, 2008). Kontrasepsi oralberpengaruh terhadap kebutuhan vitamin dan mineral pada wanita. Pertambahanberat badan disebabkan oleh hormon estrogen dan progesteron yang ada dalam pildalam penggunaan jangka waktu tertentu. Progesteron juga dapat menyebabkanpertambahan berat pada penggunaan jangka panjang akibat terjadinyaperubahan anabolik dan stimulasi nafsu makan (Ganong, 2003).

Kaur et al. (2011) menyatakan bahwa Organisasi Kesehatan Dunia(WHO) telah memulai program untuk mengembangkan pengetahuan medis tradisional.Penelitian juga dilakukan untuk pengembangan agensia antifertilitas herbal yang secara sosialdan budaya dapat diterima, memiliki kompatibilitas yang lebih baik dengan manusia, efek samping yang lebih rendah danlebih efektif dari senyawa kimia (Bala et al., 2014).

Pohon pepaya (Carica papaya Linn.), di Indonesia tersebar hampir pada semua kepulauan. Sebagian penduduk Indonesia telah terbiasa menggunakan daun papaya sebagai jamu tradisional untuk mengatasi beberapa masalah kesehatan, di antaranya sebagai bahan antifertilitas. Efek antifertilitas ekstrak tanaman telah dibuktikan oleh Gupta et al. (1990), Biji pepaya diduga bekerja dengan cara mempengaruhi sekresi hormon reproduksi (Udoh et al., 2005).Raji et al. (2005) menyatakan bahwa esktrak biji pepaya mempengaruhi sekresi hormon estrogen sehingga menyebabkan antifertilitas.

Studi fitokimia telah menunjukkan $C$. papaya mengandung alkaloid, carpain, nikotin, flavonol, tanin, dan terpene serta enzim seperti papain dan chymopapain (Adeneye et al., 2009).Bahan aktif pepaya yaitu triterpenoid merupakan salah satu turunan steroid, bahan aktif steroid dan triterpenoid diduga sebagai bahan aktif yang bekerja sebagai faktor antifertilitas. Kedua bahan aktif tersebut diduga mampu mengakibatkan gangguan pada jalur hipotalamus hipofise yang selanjutnya mengakibatkan gangguan sekresi GnRH yang kemudian akan berpengaruh terhadap pembentukan, perkembangan dan pematangan folikel(Borrow et al., 2001 ; Garor et al., 2009).Naggayi et al. (2015) menyatakan bahwa senyawa yang terkandung dalam ekstrak air biji pepaya adalah saponin, tanin, flavonol, glikosida, terpeoid, alkaloid, pereduksi gula, asam amino, lemak, protein, fenol, vitamin, sterol dan triterpene. Senyawa golongan saponin, tanin, flavonoid, terpenoid, alkaloid, sterol serta triterpene dapat menekan tingkat fertilitas dengan cara mengganggu fungsi ovarium, uterus atau vagina (Setyowati dkk., 2015).

Penelitian ini merupakan bagian dari penelitian tentangefek biji pepaya terhadap fertilitas mencit betina.Pertambahan berat badan mencit dalam hal ini diamati karena hormon steroid mempunyai pengaruh meningkatkan metabolisme tubuh.

\section{METODE PENELITIAN}

Penelitian tentang pengaruh perlakuan ekstrak air biji pepaya dengan dosis kronis terhadap pertumbuhan mencit (Mus musculus) dilakukan di Laboratorium Biologi Struktur dan Fungsi Hewan, Departemen Biologi, FSMUNDIP. Penelitian dilakukan dengan Rancangan Acak Lengkap, 5 perlakuan dan 5 ulangan.Paparan hewan uji diberikan selama 21 hari. Kelompok perlakuan terdiri dari Kontrol Negatif (K-) berupa perlakuan dengan pelarut bahan uji (air), Kontrol Positif $(\mathrm{K}+)$ berupaperlakuan dengan sediaan kontrasepsi sintetis (pil kontrasepsi merk "X"), P1 adalah kelompok perlakuan dengan bahan uji 
konsentrasi $1.4 \mathrm{mg} / \mathrm{ekor} / \mathrm{hari}, \mathrm{P} 2$ yaitu kelompok perlakuan dengan bahan uji konsentrasi 3,5 mg/ekor/hari, dan P3 yaitu kelompok perlakuan dengan bahan uji konsentrasi $7 \mathrm{mg} / \mathrm{ekor} /$ hari.

Hewan uji yang digunakan adalah mencit galur Swiss Webster betina berumur 2.5 - 3 bulan dengan rataan bobot badan 25-30 gram, tanpa cacat anatomis, diperoleh dari Laboratorium Pemeliharaan Hewan Jurusan Biologi FMIPA Universitas Negeri Semarang. Hewan uji dipelihara dengan kepadatan 3 ekor hewan per kandang, setelah diaklimasikan dalam kondisi laboratorium selama 1 minggu. Pemberian pakan dan minum dilakukan secara ad libitum. Pakan yang diberikan adalah pakan standard dengan kode 594.Pemeliharaan hewan uji dilakukan sesuai metode Sitasiwi dan Djaelani (2011).

\section{Persiapan Bahan Uji}

Bahan uji yang diberikan adalah serbuk biji pepaya. Serbuk biji pepaya diperoleh dari beberapa pohon pepaya dengan jenis yang sama, ditanam di daerah Gedawang, Banyumanik Semarang. Ekstrak biji C. papaya yang diperoleh dengan cara mencuci biji pepaya dengan air mengalir, kemudian dikeringkan menggunakan oven pada suhu $40{ }^{\circ} \mathrm{C}$ selama 10 hari. Biji $C$. papaya yang telah kering, dibuat tepung dengan cara dihancurkan dengan blender, kemudian diayak. Tepung biji C. papaya disiapkan sebagai bahan uji sesuai dengan dosis yang diberikan, dilarutkan dengan cara melarutkan tepung biji pepaya menggunakan air mendidih. Pemberian bahan uji dilakukan saat air seduhan biji pepaya telah mencapai suhu ruang.

Kelompok perlakuan kontrol positif diberi sediaan kontrasepsi sintetis berupa pil kontrasepsi merk " $\mathrm{X}$ " (mengandung ethinylestradiol $0.03 \mathrm{mg}$ dan levonorgestrel $0.15 \mathrm{mg}$ ), dengan dosis harian sesuai dosis harian pada manusia. Pil KB dihancurkan menggunakan grinder dan dilarutkan menggunakan air hangat.

\section{Perlakuan dan Pengambilan Data}

Pemberian bahan perlakuan diberikan secara oral menggunakan jarum "gavage" dengan volume $0,5 \mathrm{~mL} /$ hewan uji, pada sore hari $(15.00$ 16.00 WIB), selama 21 hari berturut-turut. Pengukuran berat badan mencit dilakukan setiap minggu sekali. Pengukuran konsumsi pakan dan konsumsi minum dilakukan setiap hari.

Data konsumsi pakan dihitung dengan cara menimbang pakan yang diberikan dikurangi sisa pakan (g/hari). Data konsumsi minum dihitung dengan cara menakar air minum yang diberikan dikurangi sisa air minum (ml/hari).

\section{Analisis Data}

Data yang diperoleh dianalisa dengan analisis varian (ANOVA). Perbedaan antar perlakuan diuji dengan DuncanTest .

\section{HASIL DAN PEMBAHASAN}

Hasil Analysis Of Varians (ANOVA) dan uji lanjut Duncan pada penelitian mengenai efek antifertilitas biji pepaya pada pertambahan berat badan menit ditunjukkan pada tabel 1 . Tabel 1 menunjukkan bahwa pertambahan berat badan mencit tidak berbeda nyata antara semua kelompok hewan uji. Hal ini menunjukkan bahwa perlakuan pemberian biji pepaya maupun pil KB dengan dosis kronis pada mencit tidak menyebabkan pertambahan berat badan. Hal ini sesuai dengan hasil penelitian Lohiya et.al. (2000) yang menyatakan bahwa pemberian ekstrak air biji pepaya dengan paparan kronis (35 hari) tidak mempengaruhi berat badan pada kelinci jantan. Penelitian Siburian dkk. (2008) menyatakan pemberian ekstrak biji pepaya dengan dosis 50,75 dan $10 \mathrm{mg} / \mathrm{kg}$ BB pada mencit betina selama 10 hari pada tahap pracopulasi tidak berpengaruh nyata terhadap berat badan.

Pertambahan berat badan pada suatu individu dipengaruhi antara lain oleh faktor nutrisi. Nutrisi pada dasarnya adalah nutrien atau zat gizi yang terdapat dalam pakan yang masuk ke dalam tubuh individu sebagai konsumsi pakan.

Konsumsi pakan mencit pada penelitian ini (Tabel 1) tampak bahwa antara $\mathrm{K}(+), \mathrm{K}(-)$, P2 dan P3 tidak berbeda nyata. Perbedaan nyata hanya terdapat antara $\mathrm{P} 1$ dengan $\mathrm{K}(+)$. Konsumsi pakan P2 sebesar 4,23 g/ekor/hari sedang $\mathrm{K}(+)$ 
sebesar 5,36 g/ekor/hari. Konsumsi pakan P1 lebih kecil daripada $\mathrm{K}(+)$. Hal ini diduga pengaruh senyawa antifertilitas dalam biji pepaya pada P1 (dosis $1,4 \mathrm{mg} / \mathrm{ekor} / \mathrm{hari}$ ) terhadap metabolisme nutrisi, perubahan anabolik maupun nafsu makan tidak sekuat yang ditimbulkan oleh sediaan hormon sintetik pada $\mathrm{K}(+)$. Sesuai dengan pernyataan Bala (2014) bahwa potensi kontrasepsi herbal lebih rendah dibandingkan kontrasepsi yang berasal dari obat sintetis

Tabel 1. Rerata Pertambahan Berat Badan, Konsumsi Pakan Harian dan Konsumsi Minum Harian Mencit Setelah Perlakuan Ekstrak Air Biji Pepaya Secara Oral Selama 21 Hari

\begin{tabular}{lccccc}
\hline & K(-) & K(+) & P1 & P2 & P3 \\
\hline $\begin{array}{l}\text { Pertumbuhan berat } \\
\text { badan (g/ekor }\end{array}$ & $0,75^{\mathrm{a}} \pm 0,473$ & $1,18^{\mathrm{a}} \pm 0,474$ & $1,37^{\mathrm{a}} \pm 0,946$ & $1,03^{\mathrm{a}} \pm 0,899$ & $0,70^{\mathrm{a}} \pm 0,572$ \\
$\begin{array}{l}\text { Konsumsi pakan } \\
\text { harian (g/ekor) }\end{array}$ & $4,43^{\mathrm{ab}} \pm 0,909$ & $5,36^{\mathrm{b}} \pm 1,069$ & $5,07^{\mathrm{ab}} \pm 0,214$ & $4,23^{\mathrm{a}} \pm 0,535$ & $4,87^{\mathrm{ab}} \pm 1,336$ \\
$\begin{array}{l}\text { Konsumsi minum } \\
\text { harian (ml/ekor) }\end{array}$ & $6,16^{\mathrm{ab}} \pm 0,695$ & $5,43^{\mathrm{a}} \pm 0,160$ & $5,67^{\mathrm{a}} \pm 1,336$ & $7,13^{\mathrm{b}} \pm 1,657$ & $6,74^{\mathrm{ab}} \pm 1,176$ \\
\hline
\end{tabular}

Keterangan:

Angka yang diikuti dengan superskrip yang sama pada baris yang sama menunjukkan perbedaan tidak nyata. K(-): kelompok perlakuan dengan pelarut bahan uji (air), $\mathrm{K}(+)$ : kelompok perlakuan dengan sediaan pil kontrasepsi sintetis, P1 : kelompok perlakuan dengan bahan uji konsentrasi $1.4 \mathrm{mg} /$ ekor/hari, P2 : kelompok perlakuan dengan bahan uji konsentrasi 3,5 mg/ekor/hari, dan P3 : kelompok perlakuan dengan bahan uji konsentrasi $7 \mathrm{mg} / \mathrm{ekor} / \mathrm{hari}$.

Senyawa antifertilitas dalam ekstrak air biji pepaya adalah saponin, tanin, flavonol, glikosida, terpeoid, alkaloid, pereduksi gula, asam amino, lemak, protein, fenol, vitamin, sterol dan triterpene (Naggayi et al., 2015). Senyawa golongan saponin, tanin, flavonoid, terpenoid, alkaloid, sterol serta triterpene dapat menekan tingkat fertilitas dengan cara mengganggu fungsi ovarium, uterus atau vagina (Setyowati dkk., 2015).

Pil konrasepsi yang diberikan pada hewan uji kelompok $\mathrm{K}+$ mengandung ethynil estradiol dan levonorgestrel. Ganong (2003) menyatakan bahwa ethynil estradiol merupakan estrogen sintetik yang memiliki potensi yang sama dengan estrogen. Hormon ini relatif aktif jika diberikan per oral karena resisten terhadap metabolisme hepatik. Aktivitas alami hormon ini relatif rendah dalam tubuh ketika diberikan lewat jalur digesti karena vena porta intestinum akan membawa ke hepar, dimana hormon tersebut diinaktivasi sebelum masuk sistem sirkulasi. Efek selektif estrogen sintetis ditentukan oleh selective estrogen receptor modification (SERMs) dan berkaitan dengan perbedaan cara kompleks reseptor-ligan untuk berikatan pada DNA. Ganong (2003) juga menyatakan bahwa levonorgestrel merupakan progesteron sintetik, memiliki efektivitas yang tinggi dan dapat diteloransi dengan baik oleh tubuh.

Bahan perlakuan berupa biji pepaya salah satu komponennya adalah alkaloid yang bersifat toksik. Eliminasi senyawa toksik melalui reaksi biotransformasi (metabolisme) dan ekskresi. Jalur eliminasi yang paling penting adalah eliminasi melalui hati (reaksi metabolisme) dan eksresi melalui ginjal. Ginjal sangat memegang peranan penting dalam mengekskresi baik senyawa eksogen (xenobiotika) maupun senyawa endogen, yang pada umumnya tidak diperlukan lagi oleh tubuh (Wirasuta dan Niruri, 2006). Pembuangan lewat ginjal membutuhkan banyak air. Konsumsi minum semua kelompok perlakuan tidak berbeda nyata dengan $\mathrm{K}(-)$, yang berbeda nyata adalah antara P2 dengan P1 dan P2 dengan $\mathrm{K}(+)$. Konsumsi minum pada perlakuan terlihat kecenderungan semakin tinggi daripada $\mathrm{K}+$. Diduga hal ini berhubungan dengan semakin tingginya kadar alkaloid dalam bahan perlakuan, sehingga membutuhkan lebih banyak air untuk membuang zat yang bersifat toksik dari dalam tubuh.

Tidak adanya perbedaan nyata pada konsumsi minum antara semua kelompok 
perlakuan dengan $\mathrm{K}(-)$ menunjukkan bahwa kandungan zat toksik dalam ekstrak air biji pepaya dengan dosis penelitian ini tidak mempengaruhi metabolisme tubuh mencit. Konsumsi minum paling tinggi adalah $\mathrm{P} 2$ yaitu sebesar $7,13 \mathrm{ml} /$ hari berbeda tidak nyata dengan P3 yaitu sebesar $6,74 \mathrm{ml} /$ hari.

\section{KESIMPULAN}

Hasil penelitian membuktikan bahwa pemberian biji pepaya dengan paparan kronis tidak mempengaruhi pertambahan berat badan mencit.

\section{DAFTAR PUSTAKA}

Adeneye, A.A. and J.A. Olagunju, 2009. Preliminary Hypoglycemic and Hypolypidemic Activities of the Aqueous Seeds Extract of Carica papaya Linn, in Wistar Rat. Biology and Medicine 1(1): 110.

Bala, K., M. Arya, and D.P. Katare, 2014. Herbal Contraceptive: An Overview. World Journal of Pharmacy and Pharmaceutical Science. 3(8): 1309-1326.

Burrow ME, Bone SM, Coelin BM, Meinik LI, Duana BN, Canter SW, Wiese TE, Cleveland TE and Mc. Lachlan JA. 2001. Phytochemical Gliceolins Isolated from Soy Medicine Antihormonal Effect Through Estrogen Receptor Alpha and Beta. J. Clin. Endocrinol. Metab. Apr. 86 (4) : 1750-1758.

Chinoy, N.J., T. Dilip, and J. Harsha, 1995. Effect of Carica papaya Seed Extract on Female Rat Ovaries and Uteri. Phytotherapy Research. 9(3): 169-175.

Ganong, W.F., 2003. Review of Medical Physiology. International Ed. Boston. Pp. 443- 446.

Garor R, Abir R, Erman A, Felz C, Nitke and Fish B. 2009. Effect of Basic Fibroblast Grotwh Factor on In Vitro Development of Human Ovarian Primordial Follicles. Fertility and Sterility 91(5): 1967-1975.
Guyton, A.C., and Hall, J.E. (2008). Buku Ajar Fisiologi Kedokteran. Edisi 11. Jakarta: EGC.

Gupta, R.S. and R. Sharma, 2006. A Review of Medicinal Plants Exhibiting Antifertility Activity in Males. Natural Product Radiance. 5(5): 389-410.

Hasan.M., Nelly,M., and Shirley,K.,2013. Hubungan Penggunaan Kontrasepsi Hormonal dengan Obesitas pada Wanita Usia Subur (WUS) di Puskesmas Wawonasa Kecamatan Singkil Manado. Jurnal e-Biomedik (e BM). 1(2) : 946-950.

Kaur, R., R. Sharma, and R. Kharb, 2011. Rising Trends towards Herbal Contraceptives. Scholars Research Library. J. Nat.Pord. Plant Resour. 1(4): 5 -12.

Lee YC, Rahman M, and Berenson AB. 2009. Early Weight Gain Predicting Hater Weight Gain among Depot Medroxy Progesterone Acetate Users. Obstet Gynecol 14(2):279-84

Lohiya, K.N, N. Pathak, P.K. Mishra and B Manivannan, 2000. Contraceptive Evaluation and Toxicological Study of Aquaeus Ekstract of The Seeds of Carica papaya in Male Rabbits. Jurnal of Ethnopharmacology, 1(17) : Abstract

Naggayi, M., N.Mukiibi, E. Iliya, 2015. The Protective Effects of Aqueous Extract of Carica papaya Seeds in Paracetamol Induced Nephrotoxicity in Male Wistar Rats. African Health Sciences. 15(2):604605

Raji, Y., A.O. Morakinyo, A.K. Oloyo, O.S.Akinsomisoye, Olufadekemi, T. Kunle-Alabi, P.R.C. Esegbue-Peters, and F.O Awobajo, 2005. Impact of the Chloroform Extract of Carica papaya Seed on Oestrous cycle and Fertility in Female Albino Rats.J.Med. Sci. 5(4): 337-343.

Ratnawati S, Isfentiani D, dan Widiasti S., 2011. Hubungan Penggunaan KB Implant dengan Peningkatan Berat Badan pada Peserta Implant di RB Kartini Surabaya. 
Jurnal Penelitian Kesehatan Suara Forikes. 2(1):164-165

Setyaningsih, Wineh R, dan Teresia RP., 2010. Dampak Kenaikan Berat Badan pada Akseptor KB Suntik DMPA terhadap Citra Tubuh di Polindes Sekar Arum kecamatan Grabagan Kabupaten Tuban. Jurnal Keperawatan. 3(1):85

Setyowati, E. A. W., A.D. R. Sri, Ashadi, dan M. Bakti, H. Arif, 2015. Aktivitas Antifertilitas Kontrasepsi Kulit Durian (Durio zibethinus Murr.) varietas Petruk. PS Pendidikan Kimia. Jurusan PMIPA FKIP UNS. Surakarta.

Sitasiwi, A.J. dan M.A. Djaelani, 2011. Studi awal upaya eksplorasi agensia imunokontrasepsi untuk regulasi fertilitas hewan liar: Profil protein selama proses implantasi embrio mencit (Mus musculus L.) BALB/c. BIOMA.13(1): 39 - 45.

Siburian, J. Marlina dan A. Johari. 2008. Pengaruh Ekstrak Biji pepaya (Carica papaya, L) pada Tahap Pra copulasi terhadap Fungsi Reproduksi Mencit (Mus musculus, L) Swiss Webster Betina. Laporan Penelitian. PS Pendidikan Biologi Jurusan Pendidikan MPA FKIP Universitas Jambi.

Udoh, P., I. Essien, and F. Udoh, 2005. Effects of Carica papaya (paw paw) Seeds Extract on the Morphology of Pituitary-Gonadal Axis of Male Wistar Rats. Phytotherapy Research. 19(12):1065-1068. 